\title{
European Sovereign Debt Crisis and its Impact on Financial Markets and Institutions
}

\begin{abstract}
Afzal Ahmad*
Assistant Professor of Accounting, International Islamic University Chittagong, Chittagong, BANGLADESH

*E-mail for correspondence: afzaliiuc@gmail.com

Cell Phone: +8801978121212

Received: Aug 21, 2015;

Accepted: Sep 4, 2015;

Published: Sep 13, 2015

Source of Support: Nil

No Conflict of Interest: Declared

ABSTRACT

This paper examines the European sovereign debt crisis that began in 2009; it mostly considers Greece and then Italy and Portugal since they were affected by the crisis. It gives the emergence and the causes of the crisis as well as its effect on their debt as a percentage to Gross Domestic Product and their Real Gross Domestic Product. It also analyses the impact on sovereign bond and its yields, the stock, gold, derivatives and forex markets, including the impact on financial institutions, it uses graphical illustrations from Bloomberg to back the analysis. It further assesses the measures taken so far by policy makers and financial institutions to curb the situation. It finally considers the impact of the crisis on financial landscape and lessons learnt from it.
\end{abstract}

Keywords: Debt Crisis, Financial Markets, Financial Institutions, Europe

\section{INTRODUCTION}

The European sovereign debt crisis was triggered by the global financial crisis which started in the United States (US) in 2007, with the collapse of over twenty-five subprime lending companies. Financial and Economic Analysts thought it would be a mild recession but it turned out to be a serious one ever since the great depression in 1929. In recession, September, 2008 when Lehman Brothers Investment Bank and AIG insurance company collapsed, the financial crisis entered a virulent phase (Mishkin, 2011). The financial crisis then caused an occurrence known as Contagion, and spread to other parts of the world.It affected the Eurozone and transformed into sovereign debt crisis, it first affected Greece and then Ireland, Portugal, Italy, Spain and to other parts of Europe. Spain and Ireland were gripped by the crisis due to the high debt of the private sector which was caused by the default of mortgage borrowers. The Eurozone countries failure to create growth to pay off their increased debt also contributed to their crisis. The crisis placed substantial pressure on the European countries' bond and also caused Greece to withdraw from the international bond market and increased bond price across the EU, which further intensified the crisis. The objective of the study is to examine an in-depth analysis of the causes and effects of the European sovereign debt crisis as well as the measurements taken to respond to the crisis.

\section{LITERATURE REVIEW}

A sovereign default is defined as the failure of a gover4nment to meet payments on its debt obligations to domestic and external creditors (Nelson, 2013). The default risk of several European countries increased excessively after the US financial crisis $2007 / 2008$, when indebted nations extended their borrowing to recover from recession. Consequently, by 2010 they were facing severe budget deficits. The European sovereign debt crisis evolved into the biggest challenge of the Eurozone as it threatened the stability of the Economic and Monetary Union, financial markets and banking systems. In January $1^{\text {st }} 1999$, the euro was officially institute as the common currency of eleven members of the EU. As of today, the Eurozone consists of eighteen countries (Eurozone Portal, 2014). When they joined the Eurozone, governments were not able to access credit markets easily and benefit from low interest rates without being monitored (lane, 2012.)The culminating event of the sovereign debt crisis happened in October 2009 when Greece announced a much higher than expected annual deficit to GDP forecast (Lane, 2012). Although in the past European economies' high budget deficits did not result in negative reaction from the markets, Greece's official announcement increased concerns about the fiscal irresponsibility of peripheral countries (Bernoth and Von Hagen 2012). According to Bernoth and Von Hagen (2012), "government bond yields include risk premiums; increasing indebtedness may cause bond yields to go up, 
thus raising the cost of borrowing and imposing discipline on governments." Government issue debt almost every week to roll their outstanding bonds. Therefore, the risk of not being able to borrow rose (Bernoth and Von Hagen et al., 2012). Due to the Financial restructuring of Greece, the fear about contagion effect on other Eurozone countries increased (DW.de, 2014). In parallel, prices of derivative instruments used by financial institutions to hedge against sovereign default risk soared (Alloway, 2013). Additionally CDS contracts were too expensive to be traded (Arghyrou, Kontonikas et al., 2012; Lucas and Schwaab et al., 2013)). In addition, consumers' concerns about insolvency increased, thus deposit were withdrawn from banks from countries where the banking system was perceived as risky (Allen and Moessner, 2012). The weaker economic environment in Europe also impact on investment banks. Europe was hit hard by the slowdown in financial markets, with investment banking fees in the region so far falling to the lowest level in ten years in 2012, according to Thomas Reuters (Sakoui, 2012). The European Stability Mechanism (ESM) was set up in 2012 as a permanent replacement for the EFSE and EFSM (ECB wp, M.D. Paries, R. Santis, 2013). As a result of the measures implemented by the European policymakers and financial institutions the bond market regained ground starting from 2013, as the borrowing cost of the PIIGS have fallen to pre-crisis levels (Alderman, 2014). The bailouts were granted under the condition that the counties implement tough austerity measures to achieve budget stability; however policymakers underestimated the effects of these measures as the countries' economic growth remain slow (Spiegel Online, 2013). An important lesson to be taken from these recent events is that a currency union should also result in a fiscal union (Dombret, 2013). Following the crisis, the financial landscape was transformed and new trends have emerged. European central banks and governments have become more involved in the financial markets to reduce the profitability of longer recessions (El-Rian, 2011).

The study first explains the main causes of the crisis and it consequences on financial market and institutions. The measures that are implemented to solve the crisis will be evaluated as well. Finally, the study examines the aftermaths of the crisis, including its effects on the financial landscape, the new trends emerging, and the lessons to be learned.

\section{Emergence of the European Sovereign Debt CRISIS AND ITS MAIN CAUSES}

The sovereign debt crisis began with macroeconomic disparities which was due to the same fiscal policies adopted by the Eurozone, which prevented them from adjusting their policies to suit the changing economic trends; causing slow growth. Also, the banking crisis which was caused by the global financial crisis and the increased household and government debt which was caused by the inception of the single currency of
European Union (EU) countries. European banking crisis caused their governments to inject huge amounts in bailing them out, to avoid greater crisis in the Eurozone and this resulted in high sovereign debt. Some banks, like Royal Bank of Scotland, had to be nationalised (Lane, 2012). Below are the main causes of the European sovereign debt crisis:

Common currency and mismanagement of public finance: EU members enjoys many economic benefits by using a single currency (Euro), they were able to borrow at lower interest rates than they could have if they were not members of the EU. Many member states especially Portugal, Italy, Greece and Spain over borrowed but could not cause enough growth in their economy. Greek government used the borrowed funds to fulfil their selfish political ambitions causing its debt to escalate to $113 \%$ in 2009 . Portugal and Italy governments were also guilt of mismanagement of funds; additionally, Portugal built stadiums for Euro 2004 which increased its capital expenditure. By decentralising fiscal policy and using one currency, one member states' debt does not become its burden alone but that of the entire Eurozone. However, each country needed different monetary and fiscal policies; this intensified the impact of the crisis on most EU countries.

Trade imbalances: There were balances of payment deficit and surpluses disparities in the Eurozone countries' trade balances during the crisis. Germany was the only country with good public debt and fiscal deficit comparative to GDP, since it modified its fiscal policy before the crisis erupted. However, countries like Greece, Italy, Spain and France had worse ones, since they could not devalue their currency.

Banking sector crisis: In 2007, over twenty five US subprime lending companies collapsed; this was caused by losses incurred in the sub-prime residential mortgages, as a result of borrowers default. This crisis greatly affected Spain and Ireland. The construction sector of Spain collapsed causing an increase in its unemployment rate, whilst Ireland's real estate sector, which was a good source of government tax revenue, bubble dried up government tax revenue. This intensified the crisis as borrowing cost increased; EU and the Internal Monetary Fund (IMF) had to bailout some of the member states like Spain, Ireland, Greece and others.

Credit rating: The credit rating agencies also fuelled the crisis when they reduced the credit worthiness of most EU states especially the Greece, Italy, Portugal, Ireland and Spain; Greek AAA rating was downgraded. This caused investors to lose confidence in their bonds and increased their interest rates. For example; the total aggregate debt of the USA and Japan was bigger than that of the Eurozone aggregate figure but they did not face hurdle like Eurozone. 
Lack of Proper Communication: If the policy makers of Euro zones countries have taken decision promptly and uniquely, the crisis will not severally affected whole EU. Moreover, it is criticised that, some decisions have been taken in favour of rich Eurozone countries. For example, in 2010, ECB increase interest rate when Germany needed it (Randow, 2012). These beliefs and other attacks have led many to target the European Monetary Union as the cause of Europe's problems, since it did not specify any action to be taken in times of debt crisis.

Other causes: Aside these causes, the EU governments' failure to immediately agree on the remedy for the crisis when it first started in Greece, caused spill over to other areas of the Eurozone. Also, the violation of the Maastricht Treaty conditions by some members like Greece and Cyprus, caused the crisis.

\section{EU COUNTRIES DEBT AS A PERCENTAGE OF GDP AND REAL GDP GROWTH}

The Maastricht Treaty created in 1992 spelt out the economic requirements, known as the 'Convergence Criteria (CC),' which a country had to satisfy before it could be part of the Eurozone. The CC was to help reduce inflation, stabilise exchange rate and provide good fiscal conditions for member countries. To be part of the EU, the state's budget deficits was not to exceed $3 \%$ of GDP and their total sovereign debt was not to exceed $60 \%$ of GDP. However, Greece and Cyprus refused to disclose the truth about their financial and economic situations before becoming members. Greece and Italy actually had high debt levels before the crisis. Eurostat reported in 2004 that, Greece's 2003 budget deficit was actually 4.6\% of GDP and not $1.7 \%$ of GDP and its government debt was also 7\% higher. It was disclosed in 2009 that Greece's budget deficit was $12.7 \%$ of GDP, which was more than twice of what the previous government had disclosed (Nowotny, 2013).

The debt as a percentage of GDP of the Eurozone increased with Greece, Portugal and Italy leading the increase; graph-1 below shows the trend of how they have all exceeded the requirement of the CC. Also, graph-2 shows the real GDP growth in the Eurozone. The growth rate decreased to negative during the crisis, indicating how bad the Eurozone economy was during the crisis and how it is still struggling to come out from the crisis.

Graph-1: showing the debt as a percentage of GDP for some EU countries; with Greece (blue) having the highest percentage

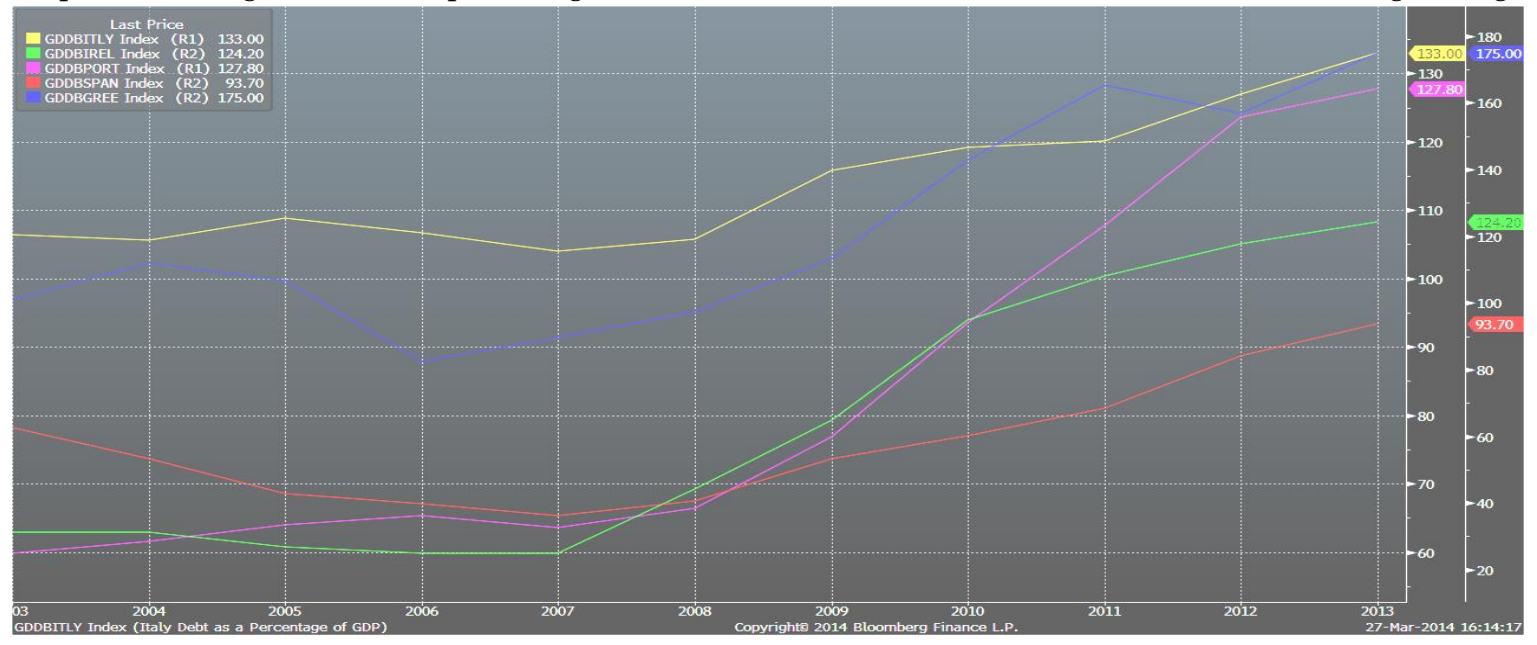

Graph-2: showing the Real GDP growth of the Eurozone

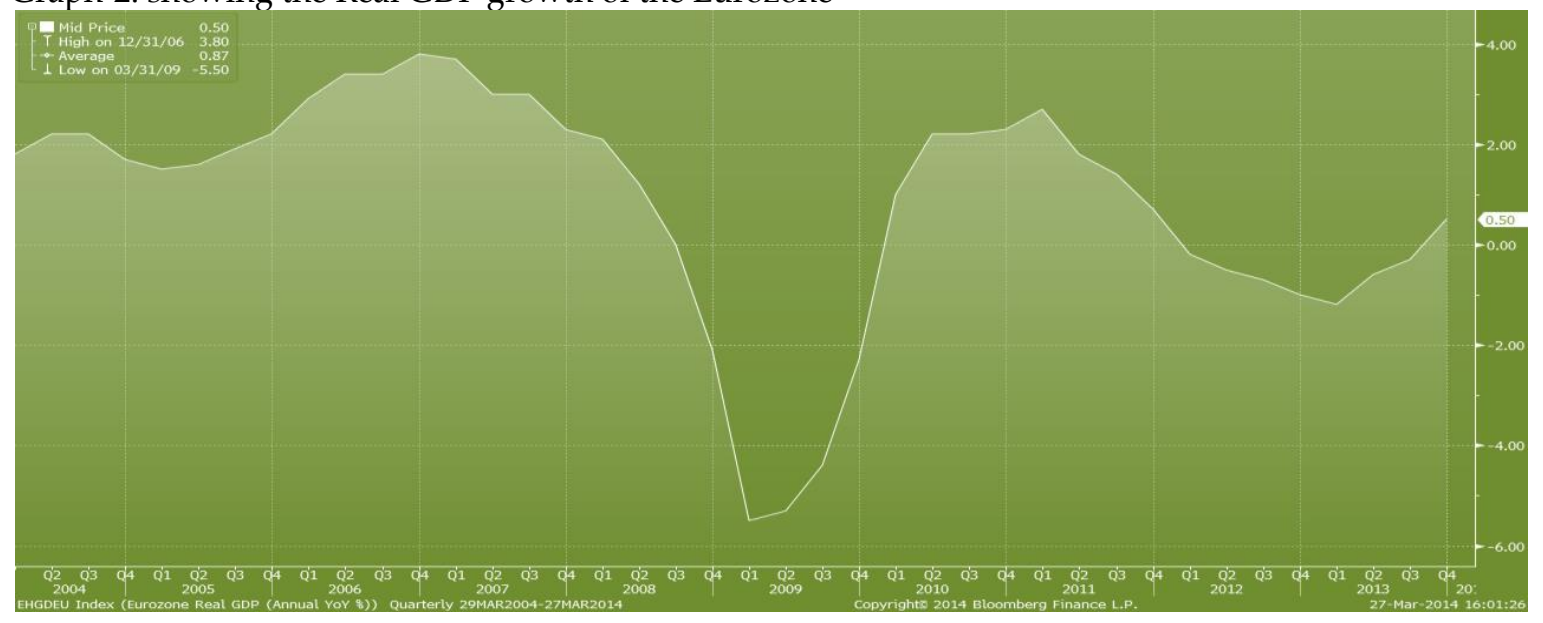




\section{IMPACT OF THE SOVEREIGN DEBT CRISIS ON BOND MARKETS AND OTHER MARKETS}

Every government wants to runs its economy well by meeting its financial needs; to satisfy this need, they issue bonds to the public and foreigners to raise their needed fund. Due to the use of single currency, countries like Greece, Italy, Spain and Portugal could issue bonds at a lower interest rate as Germany. On the inception of the crisis these countries investors lost confidence in the bonds of these countries who were heavily indebted. The downgrading of their credit worthiness by the credit agencies worsened their situation, it caused investors to withdraw from investing in those countries with the fear that they may default. This sudden attitude of investors dried up the liquidity in the financial market, investors then demanded high interest rates on the bonds of the countries like Greece, Italy, Spain and Portugal and others. This made the servicing of existing bonds difficult and the issuing of new ones more expensive. The Sovereign debt crisis remarkably affected the bond market and bond yields grew up, making it difficult for most
Eurozone governments to borrow and to bear debt. Bond yields, which show how much interest a government to investors on its bonds, increased during the European sovereign debt crisis as depicted by Graph -3. Also, the spill over effect of investors' attitude towards the bond of one EU country affected the bonds of other members and increased EU bond prices.

The crisis did not only affect the bond market but affected the stock market, gold, derivatives and other markets. The low ratings and investors perception also affected the stock markets of Eurozone countries. First, the fact that the Euro suffered substantially from the crisis and were repeatedly under pressure discouraged international investors from investing in Euro denoted stocks. This caused the price of stocks to fall which further reduced the performance and dividend yield of EU companies. The decline in the stock market is depicted by Graph -4 . Again, the derivative market experienced higher spread due to investors' perception of Eurozone countries that they may default on their debts.

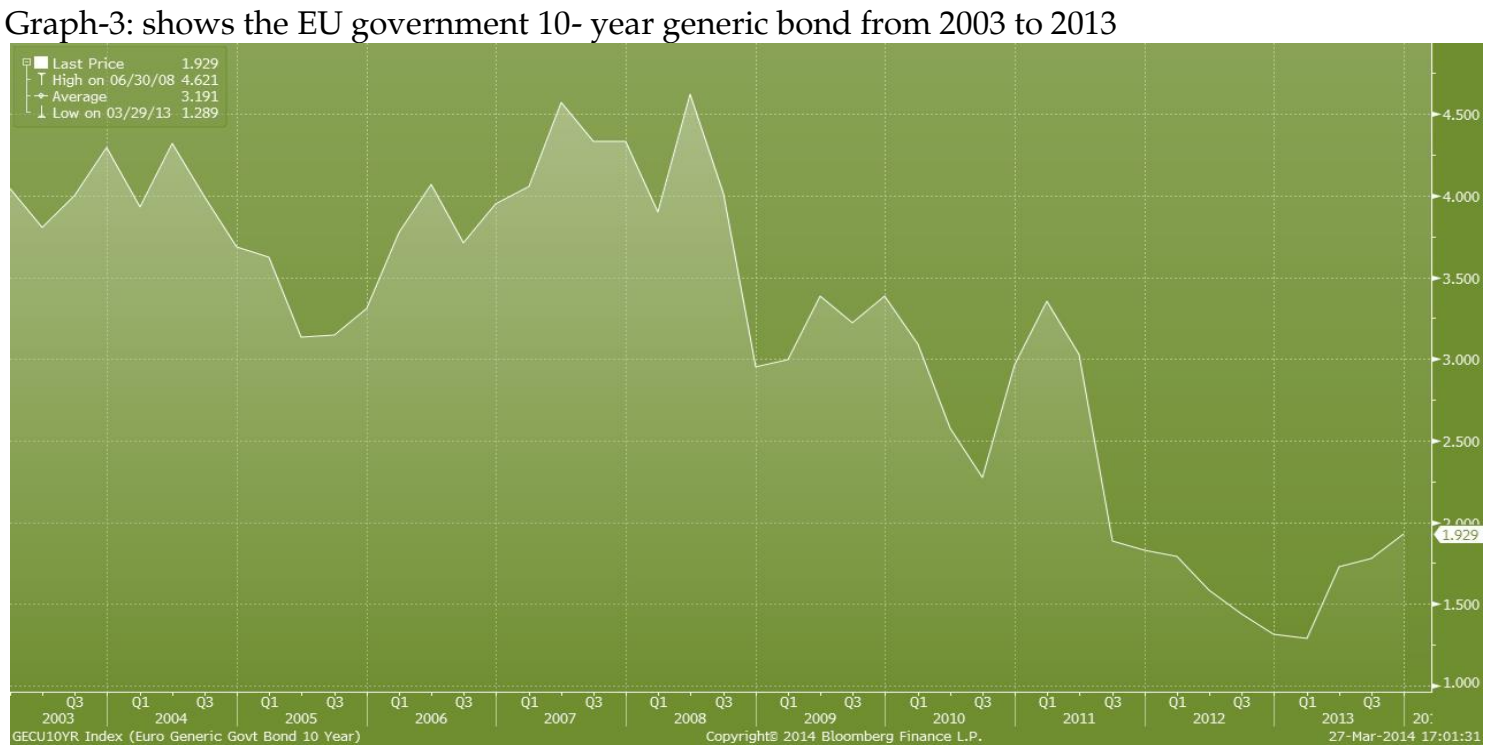

Graph-4: this graph shows the prices of 50 EU stocks from 2006 to 2013

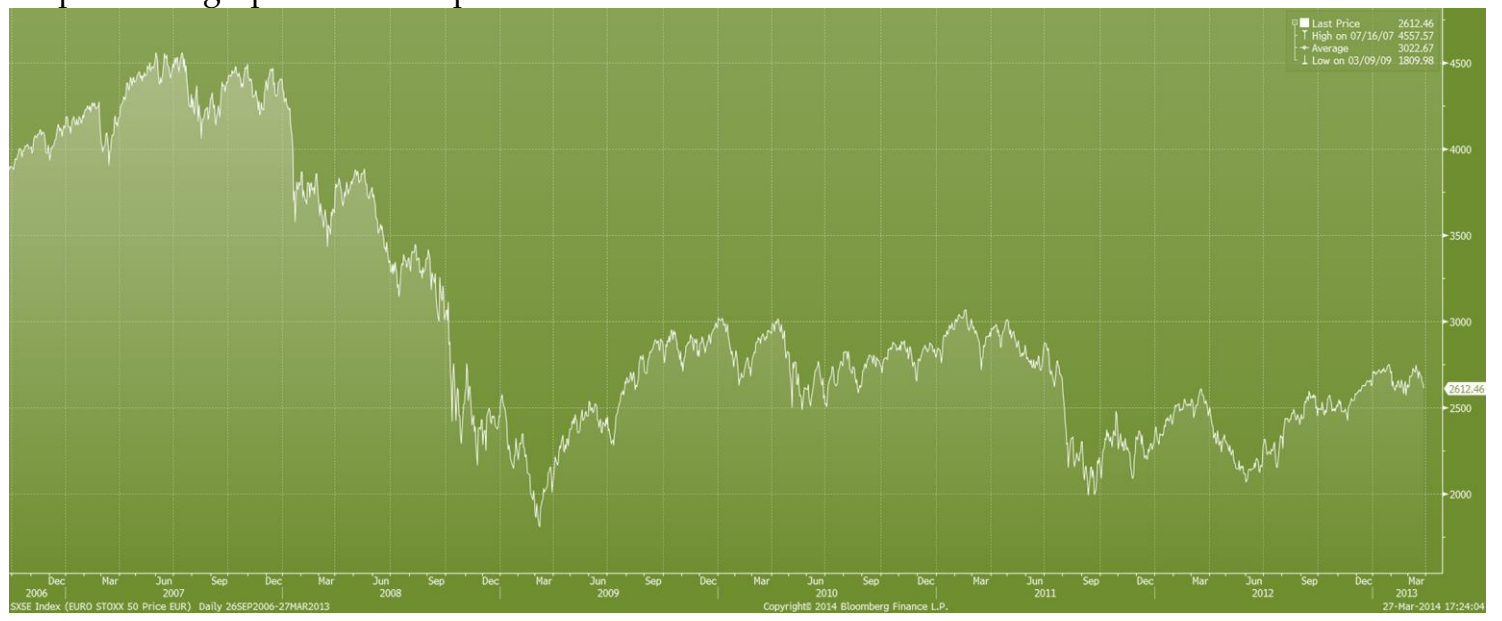


In the Forex market, the Euro declined against other major trading currencies like the US dollar. On January 2010, the value of $£ 1$ was USD \$ 1.4324. The Graph -5 below depicts the performance of the Euro, which indicates that the currency has not fully recovered from the crisis. Generally, each and every country's central bank keeps their reserve either in gold, Dollar or Euro currency. When financial crisis shaped to sovereign debt crisis many investors, for example, many Asian countries central banks like Bangladesh and India, withdraw their investment from Eurozone capital market and purchased gold as to maintain their reserve. As a result, gold price increased in a manifold. The Graph- 6 shows the gold price trend during the debt crisis.

ThisGraph-5: shows the trend of the Euro from 2006 to 2013

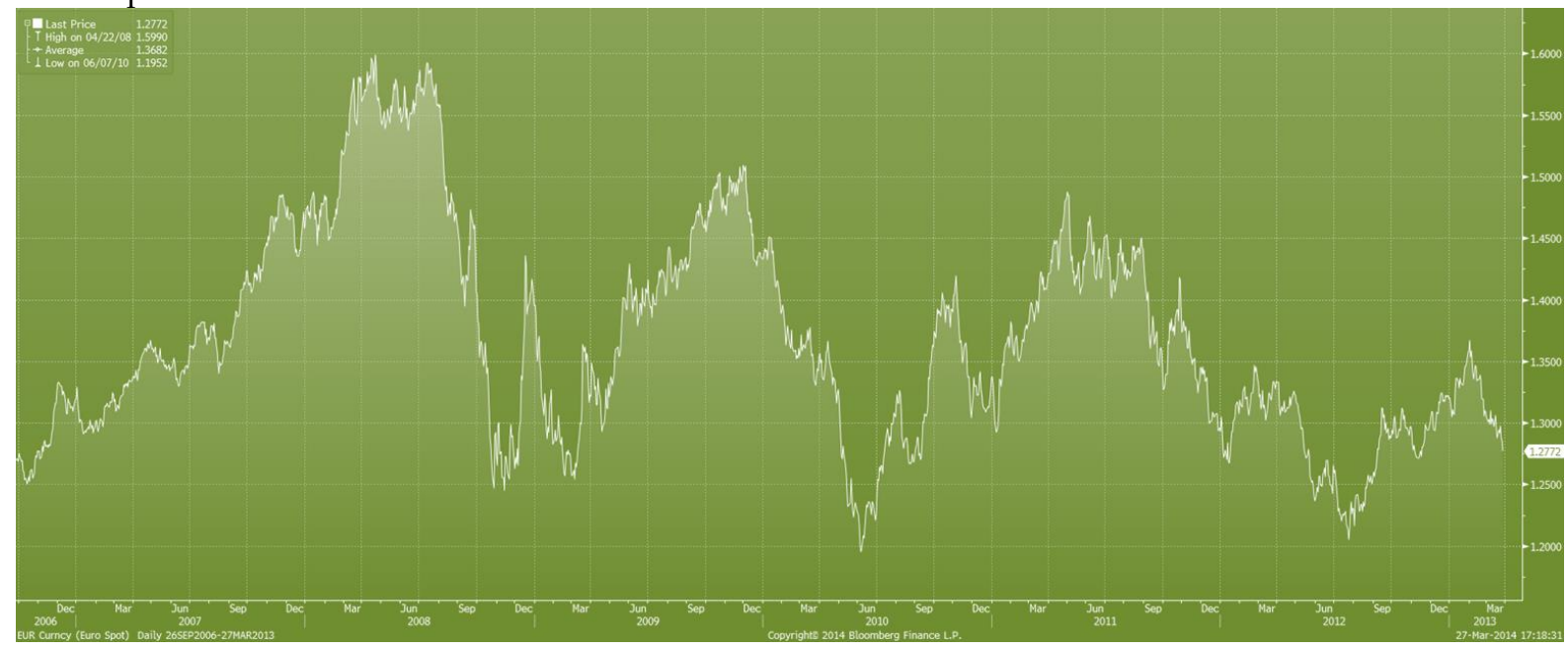

This Graph -6: shows the upward trend in the prices of Gold from 2004 to date

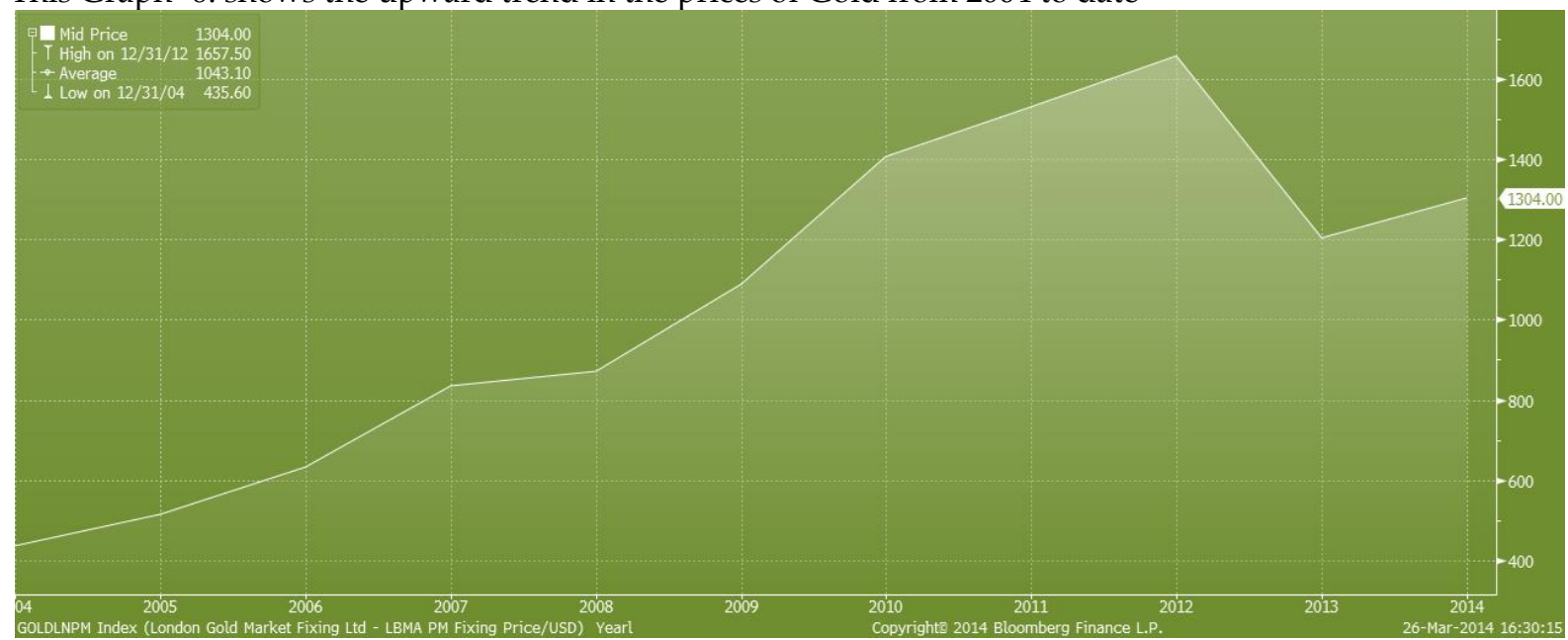

\section{IMPACT OF THE CRISIS ON FINANCIAL INSTITUTIONS}

The Eurozone sovereign debt crisis also had adverse effect on financial institutions

Due to the lack of a corporate European policy background for control the banking crisis as well as missing bank resolve mechanisms several European governments were forced to rescue troubled banks headquartered in their countries during the financial crisis. Various measures have been taken, ranging from equity injections in troubled banks to the setting-up of bad banks. Invariably, these rescue operations have increased national debt burdens and caused a deterioration of public finances (IMF, 2009). One consequence of the risk transfer from the private sector to sovereign treasuries has been an increased interdependence of banks and countries, causing negative feedback loops between their financial conditions. With the rise of the sovereign debt crisis in Europe, the link between bank and country risk has intensified further, especially for the countries that were quickly identified as vulnerable, namely: Greece, Ireland, Italy, Portugal, and Spain. 


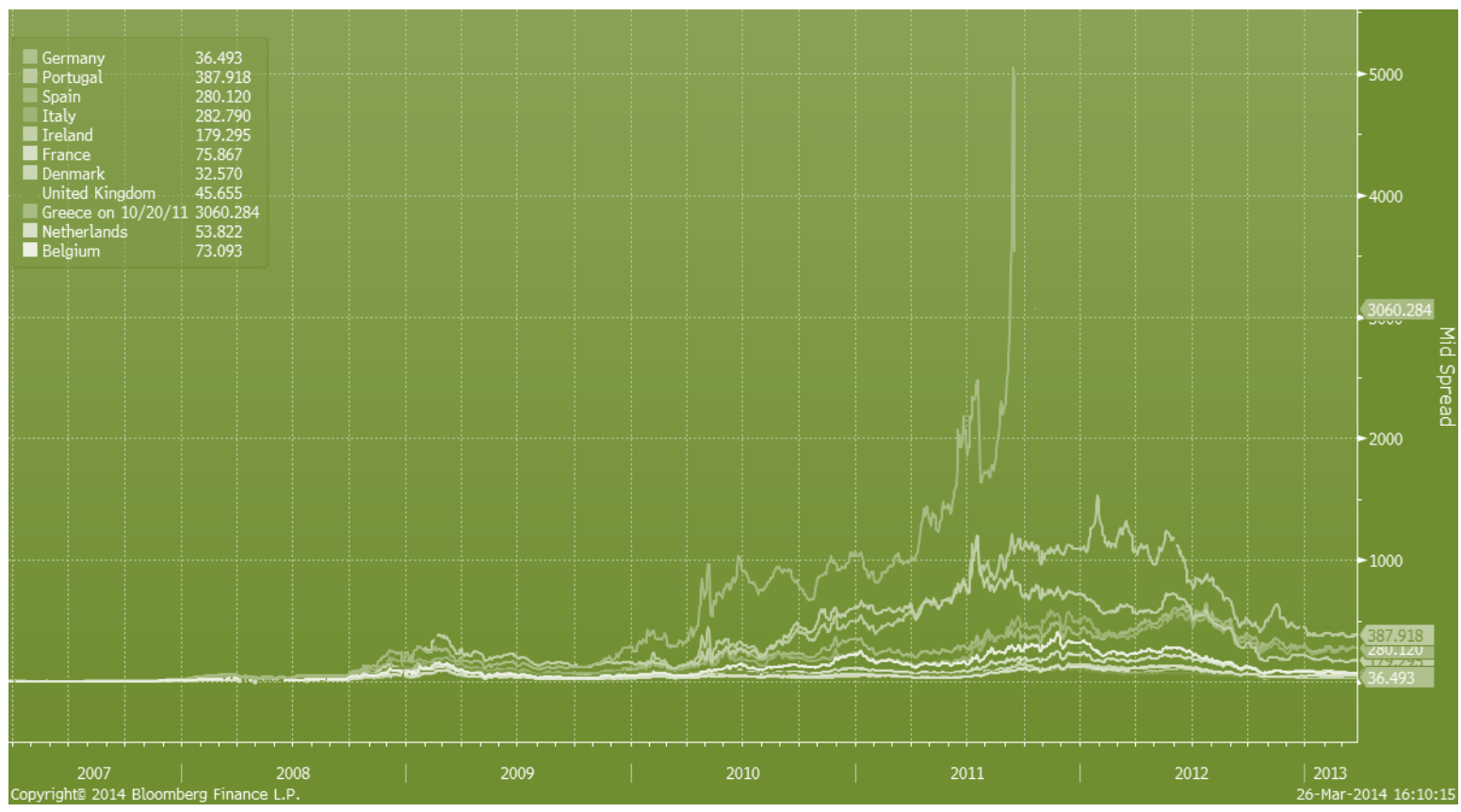

This increased interdependence is depicted in Fig show that CDS (credit default swap) spreads of the 11 countries in the sample and the average bank CDS spread for each country.

The graphs illustrate that heterogeneity is present in both the level of and the co-movement between sovereign and bank CDS spreads.

The link between the risk profile of banks and countries varies over time and is partly influenced by shocks in the economy or the banking system. A major shock stemming from the banking system was the demise of Lehman Brothers in September 2008, which provoked a substantial increase of CDS spreads for banks and also for certain countries, typically smaller countries with large banks or countries where banks had to be rescued. The sovereign debt crisis further intensified the link between bank and country risk. The sovereign debt crisis is usually considered to have started at the end of 2009, when the newly elected Greek government announced that the country's budget deficit was much larger than previously reported. In the case of Greece, two bailout packages were put together under the surveillance of the "troika" (European Commission, ECB and IMF), one of them including a substantial write-off of Greek debt in the books of private investors. Later, further rescue packages were implemented for Portugal and Ireland, both under the supervision of the troika. A series of credit rating downgrades of the affected countries followed, causing bond and CDS spreads to widen considerably (see IMF, 2009; IMF, 2010; IMF, 2011). During the sovereign debt crisis, banks in Europe were and remain confronted with stress in their capital and liquidity positions. A substantial number of banks had to rebuild their capital buffers after the losses they incurred in their securities (mainly asset backed) and lending portfolios, especially those with real estate exposures.

\section{EVALUATION OF MEASURES AND POLICIES TAKEN BY POLICY MAKERS AND FINANCIAL INSTITUTIONS}

To combat the crisis a lot of measures and policies have been implemented by the policy makers and institutions which are summarized below for the purpose of evaluation:

- Austerity Measurement: this was internal fiscal policy introduced by the EU in collaboration with the IMF, to force Eurozone states to reduce their budget deficits before they could be bailed out. With this policy, member states were to increase their taxes and cut-down government spending by reducing public sector employment and wages and that of pension fund; in order to reduce their capital expenditure. This policy seemed harsh since countries like Greece, Portugal, Spain and Ireland already had high unemployment rate.

- Financial Assistance by EU and IMF: In order to bailout Greece, European authorities agreed on a 53\% cut-off on its debt owed to private bondholders. Greece was offered $€ 110$ billion bailout loan in 2010 and another $€ 130$ billion in 2011 by the EU and IMF. These were to help Greece meet its short-term and long-term financial needs.

- European Financial Stability Facility and European Financial Stability Mechanism (EFSF/FSM): they provided $€ 440$ billion and $€ 60$ billion respectively to provide loans to EU states in crisis. It also provided the platform for Eurozone members to borrow and lend from each other and even at a cheaper interest rate on the secondary market. Again, members were able to undertake recapitalisation exercise by borrowing and investing in their financial institutions, thereby, reducing the banking crisis. However, this policy only had short-term effect of reducing sovereign interest rates since the interest 
rates increase again in some EU states. Also the $€ 500$ billion fund of EFSF/FSM is believed to be too small to solve the EU debt crisis, and raising additional fund is difficult since their bond yields are high.

- European Central Bank (ECB) was to act as Lenderof- last resort (LOLR): this role of the ECB is to purchase sovereign debt of EU countries who are affected by the crisis. This policy aims to reduce the crisis and its future occurrence, however, analysts argue that this policy would only increase the inflation in Eurozone.

- The ECB and IMF interventions: in order to ensure constant growth in the EU, the ECB implemented growth policies like the quantitative easing policy to increase the funding of banks and reduce interest rate. It also stabilised the bond rates of some EU countries to support their growth and stir up investors' confidence in the Eurozone area. The IMF also provided $€ 250$ billion loans to help in the rescuing of affected members like Greece, Portugal and Ireland.

- A general lack of trust hampered the access of banks to money market funding, which was eventually alleviated, at least temporarily, by non-conventional longer-term refinancing operations set up by the ECB. Further, the European Banking Authority (EBA) decided to conduct a sovereign stress testing exercise and required that banks execute detailed capital rebuilding plans before mid-2012. The disclosure of detailed information on banks' exposures to sovereign risk in the EBA (and former CEBS) stress testing exercises provided valuable information to market participants to gauge the risk profile of European banks. Overall, the consequence of the continued stress in the banking system and the vulnerability of certain European sovereigns is that the financial conditions of banks and sovereigns became increasingly intertwined.

\section{IMPACT ON FINANCIAL LANDSCAPE AND LESSONS TAKEN}

The European sovereign debt crisis has caused many financial and economic analysts to discuss about future possibilities of its reoccurrence. It is feared that the US, where the global financial crisis began, with huge debt, may further experience slow growth and cause more sovereign debt crisis in the future and also in the UK, if proper measures are not taken. It is, therefore important for the right measures, regulations and fiscal policies to be put in place to curb the situation and to prevent reoccurrence of such turmoil in the future.

Lessons taken from this crisis are for EU policy makers to formulate the right fiscal policies and measures to prevent an eruption in the future. This is because the crisis took the EU by surprise, and the fiscal policies could not help curtail the problem. The measures imposed on Eurozone caused over-indebtedness and slow growth in countries like the GIIPS and others; and were heavily affected by the crisis. EU must be more prepare and formulate policies and measures, in readiness to solve any of such crisis should one erupt again.

The crisis has caused uncertainty and instability in the Eurozone area since the EU serves as market and partner for countries like China and US. The recovery of the EU is very important to the world at large since the Euro is a major trading currency.

\section{CONCLUSION}

The European Union comprises of 17 countries with each country having the sovereign government who is accountable to its parliament. Therefore, lacks of unified action and proper communication among the countries worsened the situation. At the time of crisis different spokesmen of different countries, the media, as well as credit rating agencies caused investors to panic which exacerbate the crisis than actual. The bond market was seriously affected by the crisis as bond yields kept increasing during the period; others markets like the stock, gold, forex and derivatives were all affected by the sovereign debt crisis. The financial institutions were not spared as many EU mortgage lending companies collapsed, and some private banks were nationalised. Most of the measures and policies taken to curb the situation had short-term effects. Therefore, the EU authorities have to plan and make provisions to solve such situations should it happen again. Indeed, the European sovereign debt crisis did not only affect the Eurozone countries but also affected the world as a whole since many other countries trade and do business with EU states.

\section{REFERENCES}

Alderman, L. 2014. Banks Take On European Debt, Despite Underlying Problems. [online] Available at:http:/ / www.nytimes.com/2014/01/22/business/bankstake-on-european-debt despiteunderlying-problems.html [Accessed: 18 Mar 2014].

Allen, W. A. and Moessner, R. 2012. The liquidity consequences of the euro area sovereign crisis. BIS Working Papers. [report] Bank of International Settlements, pp. 1-26.

Alloway, T. 2013. Credit default swaps run out of road. [online] Available at: http://www.ft.com/cms/s/0/03cbf666-34e711e3-8148-00144feab7de.html\#axzz2vQJftDkn [Accessed: 2 Apr 2014].

Arghyrou, M. G., Kontonikas, A. and Ros. 2012. The EMU sovereign-debt crisis: Fundamentals, expectations and contagion. Journal of International Financial Markets, Institutions and Money, 22 (4), pp. 658--677.

Bernoth, K., Von Hagen, J. and Schuknecht, L. 2012. Sovereign risk premiums in the European government bond market. Journal of International Money and Finance, 31 (5), pp. 975--995.

Choudhury, A., Logutenkova, E. and Kirchfeld, A. 2012. Investment Bankers Face Termination as Europe Fees Fall. Available at: http://www.businessweek.com/news/201207-09/investment-bankers-facetermination-as-europe-feesfall\#p1 
Dombret, A. 2013. How regulation and crisis management will change the world's financial landscape. Available at: http:/ / www.bundesbank.de/Redaktion/EN/Reden/2013/ 2013_03_19_dombret_ffs.html

DW.de, 2014. Greek creditors receive official 'haircut' notification | Business | DW.DE | 24.02.2012. Available at: http://www.dw.de/greek-creditors-receive-officialhaircut-notification/a- 15767530 [Accessed: 22 Mar 2014].

ECB.2014. ECB: Banking Supervision. Available at: http:/ / www.ecb.europa.eu/ssm/html/index.en.html

El-Rian, M. 2011. Prepare for a different financial landscape. Available at: http://blogs.reuters.com/mohamed-elerian/2011/12/05/prepare-for-a-different-financiallandscape/

Eurozone Portal. 2014. The EU's response to the crisis. Available at: 23 http://www.eurozone.europa.eu/euroarea/topics/the-eus-response-to-the-crisis /

Hassan, M. (2015). Issues and Challenges of Non-Bank Financial Institutions in Bangladesh. Asian Business Review, 2(1), 61-64.

Hossain, M. (2013). Leasing: An Alternative Financing Mechanism for SMEs. ABC Journal Of Advanced Research, 2(1), 66-82.

Hossain, M., \& Hossain, M. (2015). Cost of Funds of Non-Bank Financial Institutions in Bangladesh: Internal Factors Analysis. Asian Business Review, 2(2), 29-36.

IMF. 2007. The IMF \& the European Economic and Monetary Union. [online] Available at: https://www.imf.org/external/np/exr/facts/emu.htm

Lane, P. R. 2012. The European sovereign debt crisis. The Journal of Economic Perspectives, 26 (3), pp. 49-67.

Lucas, A., Schwaab, B. and Zhang, X. 2013. Conditional euro area sovereign default risk. Journal of Business $\backslash \&$ Economic Statistics, pp. 1-30.
Nelson, R. 2013 "Sovereign Debt in Advanced Economies : Overview and Issues for Congress". CRS Report for Congress. [report] Congressional Research Service.

Nowotny, E. 2012. "European Monetary Union - lessons from the debt crisis". 40th Economics Conference of the Central Bank of the Republic of Austria Vienna, 10 May 2012.

Pal, S., \& Hossain, M. (2014). Innovations of Housing Finance Systems and the Implication in Bangladesh - A categorical study on Financial Markets. American Journal Of Trade And Policy, 1(1), 32-41.

Randow, J. 2012. Draghi Says ECB Will Do What's Needed to Preserve Euro: Economy. Available at: http:/ /www.bloomberg.com/news/2012-07-26/draghi-saysecb-to-do-whateverneeded-as-yields-threaten-europe.html

Spiegel Online. 2013. 'Notable Failures': IMF Admits Major Mistakes on Greek Bailout - Available at: http://www.spiegel.de/international/europe/the-imfadmits-serious-mistakes-ongreek-bailout-a-904093.html

Tan, A., \& Ismail, N. (2015). Foreign Direct Investment, Sovereign Debt and Growth: Evidence for the Euro Area.American Journal Of Trade And Policy, 2(1), 51-58.

Tett, G. 2014. The real titans of finance are no longer in the banks. Available at: http:/ / www.ft.com/cms/s/0/28a6bcb0-93e6-11e3-a0e100144feab7de.html\#axzz2wzrIsYgd

The Economist. 2014. What Angela isn't saying. Available at: http:/ / www.economist.com/news/finance-andeconomics/21583257-euro-zone-rescues-have-leftsovereigndebt-too-high-be-sustainable-what-angela 